\title{
Caesalpinia crista: A coastal woody climber with promising therapeutic values
}

\author{
Eric Wei Chiang Chan ${ }^{1 *}$, Joseph Tangah², Shigeyuki Baba, Hung Tuck Chan ${ }^{3}$, Mami Kainuma ${ }^{3}$, Tomomi Inoue ${ }^{4}$ \\ 'Faculty of Applied Science, UCSI University, Cheras 56000, Kuala Lumpur, Malaysia. \\ ${ }^{2}$ Forest Research Centre, Sabah Forestry Department (SFD), Sandakan 90009, Sabah, Malaysia. \\ ${ }^{3}$ Secretariat, International Society for Mangrove Ecosystems (ISME), c/o Faculty of Agriculture, University of the Ryukyus, Okinawa 903-0129, Japan. \\ ${ }^{4}$ Centre for Environmental Biology and Ecosystem Studies, National Institute for Environmental Studies (NIES), Onogawa, Tsukuba 305-0053, Japan.
}

\begin{tabular}{|c|c|}
\hline ARTICLE INFO & ABSTRACT \\
\hline Article history: & \multirow{5}{*}{$\begin{array}{l}\text { Caesalpinia crista L. is a scrambling coastal woody climber of the family Caesalpiniaceae. Leaves of C. crista are } \\
\text { bipinnate with the rachis armed with spines beneath. Flowers are yellow and fragrant, bearing } 5 \text { petals. Pods are flat and } \\
\text { have a beaked tip. Diterpenoids of the cassane and norcassane types are the major compounds isolated from C. crista. } \\
\text { Seeds of } C \text {. crista yielded cassane diterpenoids such as caesalpinins and caesalmins, and norcassane diterpenoids } \\
\text { such as norcaesalpinins. From the stems, roots and seeds, cassane diterpenoids (e.g. taepeenins A-L), and norcassane } \\
\text { diterpenoids (e.g. nortaepeenins A \& B) have been isolated. Flavonoids such as derivatives of flavones and flavanones } \\
\text { have been isolated from aerial parts and flowers. Phenolic acids such as caffeic acid, chlorogenic acid, p-coumaric } \\
\text { acid, ferulic acid and gallic acid have been identified from leaves. Pharmacological properties of } C \text {. crista include } \\
\text { antioxidant, antibacterial, antiviral, anti-malarial, anti-tumour, anticancer, anti-diabetic, anti-inflammatory, analgesic, } \\
\text { hepatoprotective, cardioprotective, anti-amyloidogenic, nootropic, wound healing, anthelmintic, insecticidal, } \\
\text { antipyretic and antiulcer activities. In conclusion, properties of C. crista exhibit potential benefits to be used for } \\
\text { pharmacological purposes. }\end{array}$} \\
\hline Received on: $29 / 11 / 2017$ & \\
\hline Accepted on: 22/02/2018 & \\
\hline Available online: $30 / 03 / 2018$ & \\
\hline $\begin{array}{l}\text { Key words: } \\
\text { Caesalpinia crista, } \\
\text { Phytochemistry, } \\
\text { Pharmacology, } \\
\text { Diterpenoids. }\end{array}$ & \\
\hline
\end{tabular}

\section{INTRODUCTION}

The genus Caesalpinia consists of $\sim 200$ species of shrubs, trees and climbers, mostly armed with spines, hooks or thorns (Khatun and Rahman, 2006; Dickson et al., 2011). Leaves are bipinnate with few to many opposite leaflets. Inflorescences are multi-flowered bearing yellow, red or variegated flowers that are bisexual, showy and medium to large. Flowers have 5 sepals, 5 petals and 10 stamens. Pods are smooth or prickly, flat or thick and often beaked. The Plant List (2013) has included 381 species of Caesalpinia of which 163 are accepted names. Geographically, Caesalpinia species are widely distributed throughout the tropics and subtropics, primarily in America and Asia, and extending to Australia, Polynesia, Madagascar and Africa (Dickson et al.,

\section{${ }^{*}$ Corresponding Author}

Eric Wei Chiang Chan, Associate Professor, Faculty of Applied Science, UCSI University, Cheras, Kuala Lumpur, Malaysia.

E-mail:chanwc@ucsiuniversity.edu.my;.erchan@yahoo.com
2011). A total of 17 species of the genus are widespread in China (Wu et al., 2011).

Plants of Caesalpinia species have been employed in folkloric medicine to treat ailments such as skin diseases, malaria, cancer, infections, erectile dysfunction, pain and wounds (Dickson et al., 2011). Of the genus, 14 species notably $C$. decapetala and C. sappan have long been used in Chinese traditional medicine for the treatment of rheumatism and inflammatory diseases (Wu et al., 2011) Leaves, barks and roots of C. pulcherrima have been used to alleviate fungal infection and fever (Pranithanchai et al., 2009).

The chemical constituents and biological activities of Caesalpinia species have been reviewed by Wu et al. (2011) and Zanin et al. (2012), respectively. Caesalpinia species are a rich source of cassane and norcassane diterpenoids (Wu et al., 2011). Other compounds include triterpenes, flavonoids, phenolic acids, sterols, aromatic phenols, etc. To date, a total 280 compounds have been reported in the genus. Pharmacologically, these species have antioxidant, antimicrobial, analgesic, adaptogenic, antiulcer, antipyretic, anthelmintic, insecticidal, anticancer, antiviral, 
immunomodulatory, immunosuppressive, antidiabetic, antiinflammatory and anti-rheumatic activities, among others (Zanin et al., 2012).

In this overview, we updated the current knowledge of phytochemical compounds isolated or identified from Caesalpinia crista including reported biological properties of compounds and extracts from this species. Endowed with cassane and norcassane diterpenoids, the species is known to have beneficial pharmacological properties such as anti-malarial, cytotoxic and anti-diabetic activities. To date, there are only two reviews on the traditional uses, and on the medicinal and pharmacological properties of $C$. crista (Suryawanshi and Patel, 2011; Al-Snafi, 2015). As an update, this review is therefore timely and appropriate.

\section{BOTANY AND USES}

Caesalpinia crista $\mathrm{L}$. is a scrambling woody climber of the family Caesalpiniaceae. According to The Plant List (2013), synonyms of $C$. crista are Caesalpinia nuga, C. paniculata, Guilandina paniculata and $G$. semina. Recent reviews on $C$. crista have included $C$. bonduc and $C$. bonducella as synonyms (Al-Snafi, 2015) and vice versa (Moon et al., 2010).

Botanical features of C. crista described here are derived from the following references (Khatun and Rahman, 2006; Giesen et al., 2007; Neli and Kalita 2013). Leaves of C. crista are bipinnate with the rachis $(10-30 \mathrm{~cm})$ armed with stout, sharp, hooked or recurved spines beneath. The pinnae (6-8 pairs) bear 2-3 pairs of leaflets that are opposite, ovate-elliptic to lanceolateovate and obtuse to shortly acute at the apex. Flowers are yellow and fragrant, bearing 5 petals. The standard petal is deep orange with red stripes. Pods are flat, rhombic-elliptic, 5-7 cm in length and have a beaked tip. Each pod contains one or two seeds that are large, rounded to ovate, hard and lustrous grey. Flowers, leaves, pods and seed of $C$. crista are shown in Figure 1.
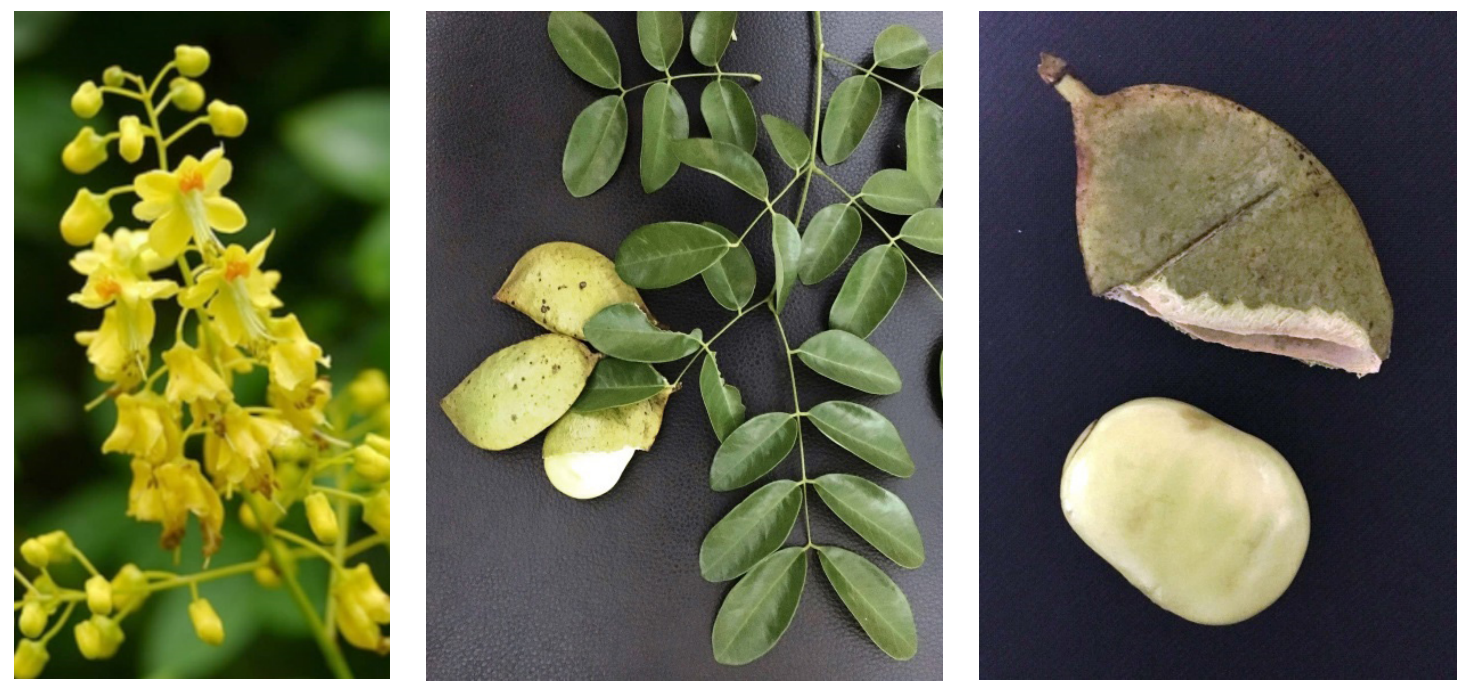

Fig. 1: Yellow fragrant flowers (left), leaves and pods (middle), and excised pod showing the seed (right) of Caesalpinia crista

In Guangdong, China, flowering and fruiting occur from February to March and from September to October, respectively (Li et al., 2004). Flowers are bisexual and protogynous, i.e. the stigma become receptive before the anthers dehisced. Anthesis was observed at 0700-0800 in the morning and flowers can last 4-5 days. Hand-pollination of flowers revealed that the species has a self-incompatible breeding system, suggesting that only crosspollinated flowers will set fruits. Bees are the main pollinators, and peak visitation is from 1000-1500 h (Neli and Kalita, 2013). Geographically, C. crista is found in South, Southeast and East Asia including the Ryukyu Islands of Japan (Giesen et al., 2007). The species has also been reported in Queensland and New Caledonia. It grows in coastal areas landward of sandy beaches and mangrove shores.

The leaves, roots and fruits of C. crista are used as tonic and antiperiodic (Cheenpracha et al., 2005). In India, Indonesia and Myanmar, its seeds have been used as an anthelmintic, antipyretic, anti-inflammatory and antimalarial drug (Banskota et al., 2003; Kalauni et al., 2006; Ramesh et al., 2010). In Assam, India, the leaves and seeds are traditionally used to treat malarial fever (Zaman et al., 2017). A root decoction has been used for the treatment of rheumatism and backache (Linn et al., 2005; Awale et al., 2006). In Perak, Malaysia, an indigenous tribe consumes the seeds of $C$. crista as condiment after crushing and mixing with fermented shrimp paste (Samuel et al., 2010).

\section{PHYTOCHEMISTRY}

Diterpenoids of the cassane and norcassane types are the major chemical constituents isolated from C. crista. From the seeds, cassane diterpenoids such as caesalpinins and caesalmins, (Kalauni et al., 2004; 2005a; 2005b) and norcassane diterpenoids such as norcaesalpinins (Banskota et al., 2003; Kalauni et al., 2004) have been identified. Caesalpinins also included cassane furanoditerpenoids (Linn et al., 2005; Kalauni et al., 2005b). Five new cassane diterpenes were isolated from seeds of $C$. crista (Kalauni et al., 2004). They were caesalpinins MA-MD with caesalpinin $\mathrm{ME}$ having a cleaved furan ring and with a bridge from $\mathrm{C}-7$ to $\mathrm{C}-17$. Cassane diterpenoids (taepeenins $\mathrm{A}-\mathrm{L}$ ), and norcassane diterpenoids (nortaepeenins A \& B) have been isolated from the stems, roots and seeds of C. crista (Cheenpracha et al., 2005; 2006). ent-11 $\beta$-Hydroxy-rosa-5,15-diene was the only rosane diterpenoid isolated. Leaves of $C$. crista yielded 
neocaesalpins $\mathrm{H} \& \mathrm{I}$ or cassane diterpene acids (Kinoshita et al., 2005) and sesterterpenoids identified as cristasesterterpenoic acid and cristasesterterpinol glucoside (Zaman et al., 2017). Flavonoids such as derivatives of flavones and flavanones have been isolated from aerial parts (Das et al., 2010) and flowers (Satnami and Yadava, 2011) of C. crista. Phenolic acids such as caffeic acid, chlorogenic acid, $p$-coumaric acid, ferulic acid and gallic acid have been identified from leaves of $C$. crista (Ramesh et al., 2014). Amongst them, gallic acid and ferulic acid were dominant.

The basic cassane skeleton is characterized by a tricyclic diterpenoid with three cyclohexane rings $\mathrm{A}, \mathrm{B}$ and $\mathrm{C}$, a substitution of ethyl group at C-13 and one methyl group at C-14 (Maurya et al., 2012). Norcassane diterpenoids have one carbon less, either at $\mathrm{C}-16$ or $\mathrm{C}-17$ (Figure 2). Among Caesalpinia species, the cassane diterpenoids are tetracyclic with ring $\mathrm{C}$ fused to a furan ring $\mathrm{D}$ at $\mathrm{C}-12$ and $\mathrm{C}-13$ (Dickson et al., 2011; Maurya et al., 2012) (Figure 3). Ring $C$ may sometimes be aromatic and has a methyl group at C-14. However, not all cassane diterpenoids have the furan ring. Cassane diterpenoids of Caesalpinia species can be classified into five basic skeleton types (Wu et al., 2011). They are: i) tricyclic fused to a furan ring; ii) tricyclic fused with an $\alpha, \beta$-butenolide; iii) tricyclic with cleavage of the furan ring; iv) rearranged furanoditerpenoids with migration of the Me group from $\mathrm{C}-4$ to $\mathrm{C}-3$; and v) furanoditerpenoid lactones constructed from ring closure involving the $\mathrm{O}$-atoms bridged to $\mathrm{C}-7$ and $\mathrm{C}-17$.
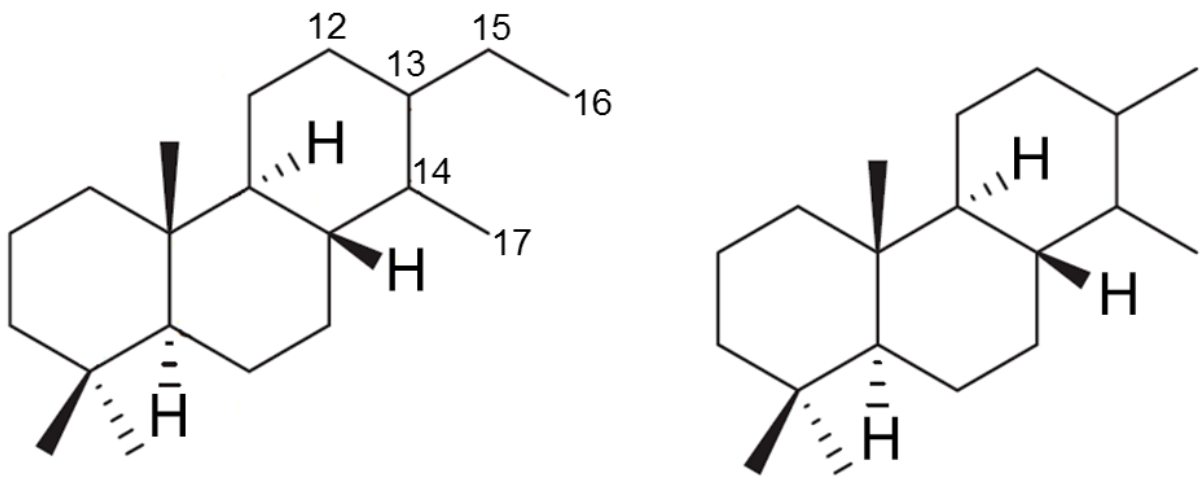

Fig. 2: Molecular skeletons of cassane (left) and norcassane (right) diterpenoids (Maurya et al., 2012).

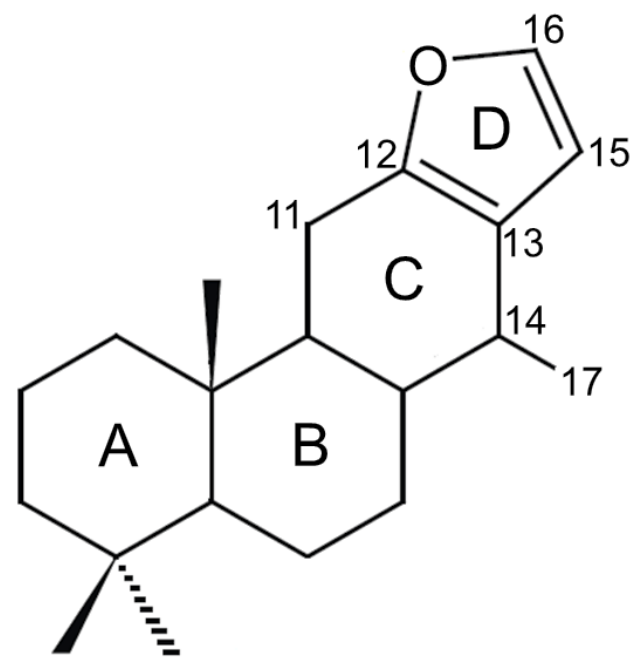

Fig. 3: Basic molecular skeleton of cassane diterpenoids of Caesalpinia species (Dickson et al., 2011).

Chromatographic analysis of the seed oil of $C$. crista showed the presence of methyl esters with dodec-9-enoate $(16.8 \%)$, palmitate $(13.3 \%)$, oleate $(12.3 \%)$, linoleate $(11.5 \%)$, 7-palmitoleate $(10.3 \%)$ and caproliate $(10.1 \%)$ as major components (Singhal, 2007).

\section{PHARMACOLOGY}

Extracts of $C$. crista possess pharmacological properties, which include antioxidant, antibacterial, antiviral, anti-malarial, anti-tumour, anticancer, anti-diabetic, anti-inflammatory, analgesic, hepatoprotective, cardioprotective, anti-amyloidogenic, nootropic, wound healing, anthelmintic, insecticidal, antipyretic and antiulcer activities. Among the different plant parts, the seeds of C. crista are noteworthy.

\section{Antioxidant}

Antioxidant properties of leaf and seed extracts of C. crista have been studied. The $70 \%$ methanol leaf extract 
was assayed using different assays for phenolic contents and antioxidant activities (Mandal et al., 2011). Total phenolic content was $50 \mathrm{mg} \mathrm{GAE} / \mathrm{ml}$ while total flavonoid content was $107 \mathrm{QE} / \mathrm{ml}$. Total antioxidant activity based on trolox equivalent antioxidant capacity (TEAC) was 0.6 . $\mathrm{IC}_{50}$ values of scavenging were 0.4 , $25,34,61$ and $170 \mu \mathrm{g} / \mathrm{ml}$ for ROS of hydroxyl, superoxide, nitric oxide, singlet oxygen and hypochlorous acid, respectively. For in vivo experiments, oral administration of the leaf extract to normal mice for a week significantly enhanced the activity of antioxidant enzymes (Mandal et al., 2011). At $300 \mu \mathrm{g} / \mathrm{ml}$, the ethanol seed extract of C. crista exhibited DPPH and $\mathrm{H}_{2} \mathrm{O}_{2}$ radical scavenging activities of $74 \%$ and $78 \%$, as compared to $87 \%$ and $80 \%$ of ascorbic acid used as control, respectively (Gill et al., 2012). Leaf extracts of $C$. crista possessed antioxidants that are able to induce protection against DNA and membrane damage (Kumar et al., 2017).

\section{Antibacterial and antiviral}

Phytochemical study on the methanol leaf extract of $C$. crista afforded 2-hydroxytrideca-3,6-dienyl-pentanoate, octacosa-12,15-diene, along with 3-O-methylellagic acid 3'- $O-\alpha$ rhamnopyranoside and $\beta$-sitosterol (Kumar et al., 2014). All the isolated compounds, extract and fractions were evaluated for in vitro antibacterial activity against various Gram-positive and Gram-negative bacteria. They were found to be significantly active against Staphylococcus aureus and methicillin-resistant $S$. aureus with MIC ranging from 64-512 $\mu \mathrm{g} / \mathrm{ml}$. Against paramyxovirus and orthomyxovirus, significant or complete inhibition was exhibited by aqueous, ethanol and methanol extracts of C. crista (Patil and Sharma, 2012).

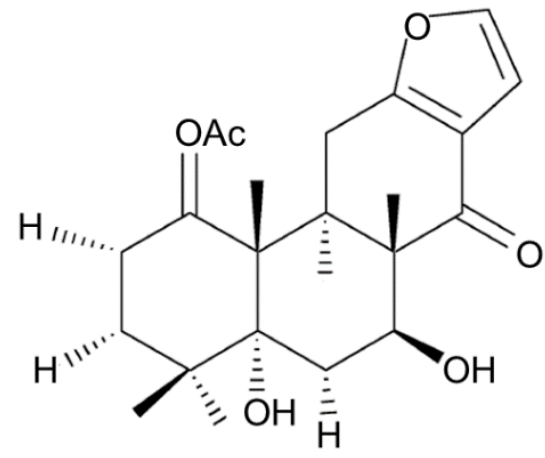

\section{Anti-malarial}

A preliminary study on the dichloromethane extract of C. crista seeds from Indonesia showed significant in vivo antimalarial activity against the growth of Plasmodium bergi in mice (Banskota et al., 2003). Consequently, cassane and norcassane diterpenoids isolated from the same extract of $C$. crista seeds from Indonesia (Linn et al., 2005) and Myanmar (Kalauni et al., 2006) exhibited significant dose-dependent inhibitory effects on the growth of Plasmodium falciparum (FCR-3/ A2) in vitro. Four compounds (norcaesalpinin E, 2-acetoxy3-deacetoxycaesaldekarin e, 14(17)-dehydrocaesalpin $\mathrm{F}$ and norcaesalpinin B) were found to be more potent than the wellknown anti-malarial drug, chloroquine (Linn et al., 2005). Eight compounds were more potent than chloroquine, with $\mathrm{IC}_{50}$ value $0.29 \mu \mathrm{M}$ (Kalauni et al., 2006). The most potent inhibitory activity was observed in norcaesalpinin E $(0.09 \mu \mathrm{M}), 2$-acetoxy3-deacetoxycaesaldekarin e $(0.10 \mu \mathrm{M})$, bonducellpin $(0.12 \mu \mathrm{M})$ and norcaesalpinin $\mathrm{F}(0.14 \mu \mathrm{M})$. The molecular structures of norcaesalpinin E and 2-acetoxy-3-deacetoxycaesaldekarin e are shown in Figure 4. Kalauni et al. (2006) concluded that the presence of an acetoxyl group at C-1 and a hydroxyl group at C-7, including the type of substituents on ring $\mathrm{C}$, are important for the antimalarial activity. Of 14 compounds isolated from stems and roots of $C$. crista and tested for anti-malarial activity, only ent$11 \beta$-hydroxy-rosa-5,15-diene exhibited significant activity with $\mathrm{ED}_{50}$ value of $4.1 \mu \mathrm{g} / \mathrm{ml}$ (Cheenpracha et al., 2005). Anti-malarial activity has also been reported in other Caesalpinia species such as C. volkensii (Kuria et al., 2001), C. pluviosa (Kayano et al., 2011), C. minax (Ma et al., 2014) C. bonduc (Ogunlana and Ogunlana, 2015) and C. sappan (Ma et al., 2015).

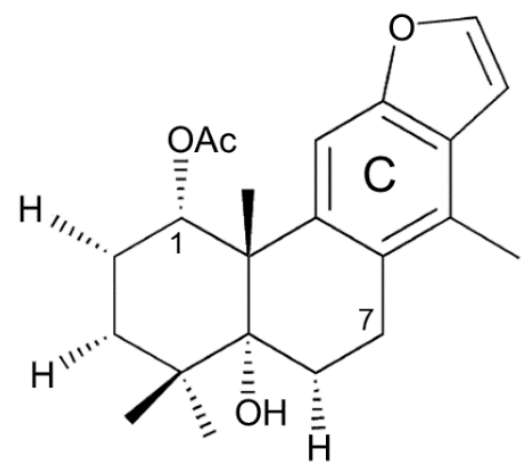

Fig. 4: Molecular structures of norcaesalpinin E (left) and 2-acetoxy-3-deacetoxycaesaldekarin e (right) (Kalauni et al., 2006).

\section{Anti-tumour and anticancer}

The ethanol root bark extract of $C$. crista was found to have significant anti-tumour activities in the Ehrlich ascites carcinoma-bearing mice (Bodakhe et al., 2011). At $150 \mathrm{mg} / \mathrm{kg}$ dose, the extract increased the life span of the mice by decreasing the nutritional fluid volume and arresting the tumour growth. Cassanetype diterpenoids isolated from $C$. crista have been reported to possess cytotoxic activity towards human cancer cell lines. Two cassane diterpenoids (6 $\beta$-cinnamoyloxy-7 $\beta$-acetoxyvouacapen$5 \alpha$-ol and $6 \beta, 7 \beta$-dibenzoyloxyvouacapen-5 $\alpha$-ol) isolated from the aerial parts of $C$. crista were reported to display moderate cytotoxic activity towards human cancer cell lines (Das et al., 2010). Against HL-60 and HeLa cancer cells, their $\mathrm{IC}_{50}$ values were 17.4 and $33.4 \mu \mathrm{M}$, and 19.8 and $33.9 \mu \mathrm{M}$, respectively. Another cassane diterpene ( $1 \alpha$-acetoxy- $5 \alpha, 7 \beta$-dihydroxycassa11,13(15)-diene-16,12-lactone) isolated from C. crista, was reported to show significant inhibitory activities against human T47D and DU145 cancer cells (Tian et al., 2013). Taepeenin D, isolated from the roots and stems of $C$. crista (Cheenpracha et al., 2005 ; 2006), was found to have significant cytotoxicity against PANC1 and DU145 cancer cells, and to inhibit the Hedgehog signalling pathway (Rifai et al., 2010; Nakazawa et al., 2016). 
The pathway controls cell growth and proliferation, and abnormal activation of Hedgehog signalling has been implicated in the development of certain types of cancer (Abidi, 2014). Recently, two fragments of taepeenin D have been synthesised for study of the structure-activity relationships and subsequently for total synthesis (Nakazawa et al., 2016). Anticancer activity has also been reported in other Caesalpinia species such as C. pulcherrima (Das et al., 2010), C. sappan (Ma et al., 2015) and C. mimosoides (Palasap et al., 2013).

\section{Anti-diabetic}

The antidiabetic activity of ethanol and aqueous seed extracts of C. crista was evaluated in streptozotocin-induced diabetic mice (Gupta et al., 2013). Both the extracts showed antidiabetic activity. There was a significant decrease in serum glucose, cholesterol and triglyceride when compared with the diabetic untreated group after 3 weeks of treatment. Treatment with the extracts also affected physical parameters such as decrease in body weight, and increase in food and water intake.

\section{Anti-inflammatory and analgesic}

Seeds of $C$. crista have been reported to possess antiinflammatory and analgesic properties (Gill et al., 2012). Using the carrageenan-induced paw oedema method, the ethanol seed extract showed maximum inhibition of $74 \%$ at $300 \mathrm{mg} /$ $\mathrm{kg}$. Diclofenac, the standard, had a value of $88 \%$ at $13 \mathrm{mg} / \mathrm{kg}$. The extract at $300 \mu \mathrm{g} / \mathrm{ml}$ concentration showed potent analgesic activity of $71 \%$ based on writhing reflexes in mice and $5.3 \mathrm{sec}$ tail withdrawal latency using the tail immersion method. The aqueous extract of $C$. crista leaves was reported to inhibit 5-lipoxygenase with an $\mathrm{IC}_{50}$ value of $23 \mu \mathrm{g} / \mathrm{ml}$ compared to nordihydroguaiaretic acid used as the control which had an $\mathrm{IC}_{50}$ value of $8.6 \mu \mathrm{g} / \mathrm{ml}$ (Ramesh et al., 2014). 5-Lipoxygense is a key enzyme in the biosynthesis of leukotriens, which are implicated in inflammatory and allergic reactions.

\section{Hepatoprotective}

The ameliorative effect the aqueous methanol leaf extract of $C$. crista on iron-overload-induced liver injury has been reported (Sarkar et al., 2012). The extract attenuated the increase in liver iron and serum ferritin levels, and also showed inhibition of lipid peroxidation, protein oxidation and liver fibrosis. Enhanced levels of liver antioxidant enzymes were detected in the treated group, which also had significantly increase in the release of ferritin iron. The extract exhibited DPPH radical scavenging and protection against $\mathrm{Fe}^{2+}$-mediated oxidative DNA damage. A recent publication reaffirmed the hepatoprotective properties of C. crista (Gupta et al., 2014). Results of the study showed that the ethanol extract of C. crista seeds at 100 and $200 \mathrm{mg} / \mathrm{kg}$ was able to normalise the biochemical levels in the serum and histopathological changes in the liver of albino rats, altered by carbon tetrachloride $\left(\mathrm{CCl}_{4}\right)$ and paracetamol intoxication.

\section{Cardioprotective}

The alcohol and aqueous seed extracts of C. crista was evaluated for their protective effects on against isoproterenolinduced myocardial infarction in albino rats (Kumar et al., 2013). The induced heart damage resulted in elevated levels of enzymes in the serum with increased lipid peroxide and reduced glutathione content in the heart homogenate. Pre-treatment with the extracts at a dose of $400 \mathrm{mg} / \mathrm{kg}$, orally for 30 days, reduced significantly the elevated enzyme levels in the serum and heart homogenate. Histopathological examination also showed marked protection by the extract against myocardial necrotic damage.

\section{Anti-amyloidogenic and nootropic}

Alzheimer's disease, characterized by loss of memory, cognitive dysfunction and alterations in behaviour, is widely believed to be driven by the production and deposition of amyloid beta $(A \beta)$ peptides (Selkoe, 2001; Murphy and LeVine III, 2010). The self-assembling monitoring of $A \beta$ in vitro provides an opportunity to screen drugs for anti-amyloidogenic properties. A study on the effects of $C$. crista aqueous leaf extract on the formation of oligomers and aggregates from monomers, and on the formation of fibrils from oligomers has been conducted using the thioflavin-T assay and transmission electron microscopy (Ramesh et al., 2010). Results showed that the extract was able to inhibit $\mathrm{A} \beta(42)$ aggregation from monomers and oligomers, and to dis-aggregate pre-formed fibrils. The aqueous seed extract of $C$. crista has been examined as a learning and memory enhancer (a nootropic drug) in mice with scopolamine-induced amnesia using the radial arm maze and the Morris water maze (Kshirsagar et al., 2011). Mice treated with 50 and $150 \mathrm{mg} / \mathrm{kg}$ of the extract was found to have memory retention of $33 \%$ and $45 \%$ compared to $26 \%$ of the amnesic group in the arm maze. Learning performance based on average time taken for three successful trials was 65 and $58 \mathrm{sec}$ compared to $113 \mathrm{sec}$ of the amnesic group. In the arm maze, memory retention was $39 \%$ and $52 \%$ compared to $15 \%$ of the amnesic group while learning performance was 33 and $23 \mathrm{sec}$ compared to $38 \mathrm{sec}$ of the amnesic group.

\section{Wound healing}

The wound healing activity of different extracts and fractions of seeds of C. crista has been studied using the excision, incision and dead space wound models in albino rats (Patil, 2005). Results showed that the group orally administered with the ethyl acetate fraction was the most effective. Closure of excision was $21 \%$ at day 4 and $100 \%$ at day 20 . Values of the control group were $12 \%$ and $77 \%$ for the same duration. Tensile strength of the healing incision and dead space wounds was $285 \mathrm{~g}$ and $305 \mathrm{~g}$, compared to the control group of $144 \mathrm{~g}$ and $157 \mathrm{~g}$, respectively.

\section{Anthelmintic}

The anthelmintic activity of the aqueous methanol extract of $C$. crista seeds has been demonstrated in vitro against the sheep nematode Haemonchus contortus using the adult motility assay and the egg hatch test (Jabbar et al., 2007). In the adult motility assay, all the worms were found dead after $6 \mathrm{~h}$ of exposure to different concentrations of the extract. In the egg hatch test, the extract had a $\mathrm{LC}_{50}$ value of $0.13 \mathrm{mg} / \mathrm{ml}$. In vivo, the maximum reduction in nematode eggs per gram of sheep faeces was recorded as $94 \%$ at $3.0 \mathrm{~g} / \mathrm{kg}$ on day 13 . The seed powder of $C$. crista was serially extracted with different solvents and tested for in vitro anthelmintic activity against earthworms (Singhal, 2007). Results indicated that the anthelmintic activity of petroleum ether extract was good with lethal time of 15 and $22 \mathrm{~min}$ at $4 \%$ and $2 \%$ 
concentration, respectively. Ranking of anthelmintic activity was of the order: petroleum ether extract $>$ benzene extract $>$ alcohol extract. Recently, a similar study reported anthelmintic activity of different seed extracts (petroleum ether, ethyl acetate, ethanol and aqueous) of $C$. crista using earthworms Pheretima posthuma and roundworms Ascardia galli (Bhardwaj et al., 2016). Results showed that all the extracts displayed anthelmintic activity based on the time of paralysis and death. Notably were values of the ethanol and aqueous extracts at $15 \% \mathrm{w} / \mathrm{v}$, which were comparable to piperazine citrate used as the control.

\section{Insecticidal}

The insecticidal effects of $C$. crista seed extracts against Helicoverpa armigera (Lepidoptera) and its predator, Coccinella septumpunctata (Coleoptera) have been reported (Nathala and Dhingra, 2006). The extracts exhibited strong anti-feedant and growth disruption activity of $H$. armigera. Toxic symptoms were mortality and weight reduction of larvae and pupae, and malformation of adults. Against C. septumpunctata, there was no mortality of adults up to nine days after treatment.

\section{Antipyretic}

Ethanol and aqueous extracts of $C$. crista seeds have antipyretic or fever reduction effects on experimental animals (Ishan et al., 2013). The extracts were tested on Brewer's yeastinduced pyrexia in rats, on typhoid and paratyphoid A \& B vaccine-induced pyrexia in rabbits and on boiled milk-induced pyrexia in rabbits. In all three models, there was decline in the rectal temperature of the animals following administration of the extracts. The ethanol extract showed antipyretic activity comparable to that of paracetamol, the standard drug.

\section{Antiulcer}

The extracts of $C$. crista seeds exhibited significant antiulcer activity in rats using the pylorus ligation and indomethacineinduced ulcer models (Chauhan et al., 2015). Oral administration of the ethanol extract at $200 \mathrm{mg} / \mathrm{kg}$ dose had maximum effects with ulcer score and ulcer index of 0.52 and 3.44 compared to the control of 4.16 and 11.1, respectively. Its ulcer protection index of $69 \%$ was comparable to $85 \%$ of Ranitidine used as the reference standard drug. In addition, there was decrease in the volume of gastric juice, free acidity and total acidity in the animals treated with the extracts.

\section{CONCLUSION}

Diterpenoids of the cassane and norcassane types are the major compounds isolated from C. crista. These diterpenoids are of interest due to their structural diversity and their broad spectrum of pharmacological properties, which include antioxidant, antibacterial, antiviral, anti-malarial, anti-tumour, anticancer, anti-diabetic, anti-inflammatory, analgesic, hepatoprotective, cardioprotective, anti-amyloidogenic, nootropic, wound healing, anthelmintic, insecticidal, antipyretic and antiulcer activities. Further studies are needed to identify the bioactive compounds responsible and their roles for each of the pharmacological properties.

\section{ACKNOWLEDGEMENT}

The authors are grateful to Dauni Seligi, Jamiss Aribin and Fabian Koret, field staff from the Sabah Forestry Department in Sandakan, Sabah, who have been monitoring and photographing the flowering and fruiting of C. crista when they go out on their field trips.

\section{REFERENCES}

Abidi A. Hedgehog signalling pathway: A novel target for cancer therapy. Indian J Pharmacol, 2014; 46: 3-12.

Al-Snafi AE. Pharmacology and medicinal properties of Caesalpinia crista - An overview. Int J Pharm, 2015; 5: 71-83.

Awale S, Linn TZ, Tezuka Y, Kalauni SK, Banskota AH, Attamimi F, Ueda JY, Kadota S. Constituents of Caesalpinia crista from Indonesia. Chem Pharm Bull, 2006; 54: 213-218.

Banskota AH, Attamimi F, Usia T, Linn TZ, Tezuka Y, Kalauni SK, Kadota S. Novel norcassane-type diterpene from the seed kernels of Caesalpinia crista. Tetrahedron Lett, 2003; 44: 6879-6882.

Bhardwaj LK, Chandrul KK, Sharma US. Evaluation of anthelmintic activity of Caesalpinia crista Linn. seed extracts. World J Pharm Pharm Sci, 2016; 5: 976-982.

Bodakhe SH, Agrawal A, Agrawal A, Shinde N, Namdeo KP. Anticancer study on alcoholic extract of Caesalpinia crista root bark extract. J Pharm Res Opin, 2011; 1: 126-128.

Chauhan P, Gupta N, Safhi MM, Nomier Y, Agarwal M, Nayem M. Evaluation of anti-ulcer activity of Caesalpinia crista Linn. Seeds on pylorus ligation and indomethacine induced gastric lesions in albino rats. Int J Res Pharm Sci, 2015; 5: 9-13.

Cheenpracha S, Srisuwan R, Karalai C, Ponglimanont C, Chantrapromma S, Chantrapromma K, Fun HK, Anjum S. New diterpenoids from stems and roots of Caesalpinia crista. Tetrahedron, 2005; 61: 8656-8662.

Cheenpracha S, Karalai C, Ponglimanont C, Chantrapromma $\mathrm{K}$, Laphookhieo S. Cassane-type diterpenes from the seeds of Caesalpinia crista. Helv Chim Acta, 2006; 89: 1062-1066.

Das B, Srinivas Y, Sudhakar C, Mahender I, Laxminarayana K, Reddy PR, Raju TV, Jakka NM, Rao JV. New diterpenoids from Caesalpinia species and their cytotoxic activity. Bioorg Med Chem Lett, 2010; 20: $2847-$ 2850 .

Dickson RA, Fleischer TC, Houghton PJ. Cassane-type diterpenoids from the genus Caesalpinia. Pharmacogn Commun, 2011; 1: 63-77.

Giesen W, Wulffraat S, Zieren M, Scholten L. Caesalpinia crista. In: Mangrove Guidebook for Southeast Asia. Food and Agricultural Organisation (FAO) and Wetlands International, Bangkok, Thailand, 2007; p. 465.

Gill NS, Kaur R, Arora R, Bali M. Phytochemical investigation of Caesalpinia crista seed extract for their therapeutic potential. Res J Med Plants, 2012; 6: 100-107.

Gupta N, Sharma I, Agarwal M, Mohammed SM, Chauhan P, Anwer T, Khan G. Antidiabetic activity of seed extracts of Caesalpinia crista Linn. in experimental animals. Afr J Pharm Pharmacol, 2013; 7: 1808-1813.

Gupta N, Chauhan P, Nayeem M, Safhi MM, Agarwal M. Hepatoprotective effect of Caesalpinia crista Linn. against $\mathrm{CCl}_{4}$ and paracetamol induced hepatotoxicity in albino rats. Afr J Pharm Pharmacol, 2014; 8: 485-491.

Ishan S, Nakul G, Safhi MM, Agrawal M, Prerna C. Antipyretic activity of Caesalpinia crista Linn. seed extract in experimental animals. Int J Curr Res, 2013; 5: 1202-1205.

Jabbar A, Zaman MA, Iqbal Z, Yaseen M, Shamim A. Anthelmintic activity of Chenopodium album (L.) and Caesalpinia crista (L.) against trichostrongylid nematodes of sheep. J Ethnopharmacol, 2007; 114: 86-91.

Jadhav AN, Kaur N, Bhutani KK. A new furanoditerpenoid marker for the distinction between the seeds of two species of Caesalpinia. Phytochem Anal, 2003; 14: 315-318.

Kalauni SK, Awale S, Tezuka Y, Banskota AH, Linn TZ, Kadota S. Cassane- and norcassane-type diterpenes of Caesalpinia crista from 
Myanmar. J Nat Prod, 2004; 67: 1859-1863.

Kalauni SK, Awale S, Tezuka Y, Banskota AH, Linn TZ, Kadota S. New cassane-type diterpenes of Caesalpinia crista from Myanmar. Chem Pharm Bull, 2005a; 53: 214-218.

Kalauni SK, Awale S, Tezuka Y, Banskota AH, Linn TZ, Kadota S. Methyl migrated cassane-type furanoditerpenes of Caesalpinia crista from Myanmar. Chem Pharm Bull, 2005b; 53: 1300-1304.

Kalauni SK, Awale S, Tezuka Y, Banskota AH, Linn TZ, Asih PB, Syafruddin D, Kadota S. Antimalarial activity of cassane- and norcassane-type diterpenes from Caesalpinia crista and their structureactivity relationship. Biol Pharm Bull, 2006; 29: 1050-1052.

Kayano AC, Lopes SC, Bueno FG, Cabral EC, Souza-Neiras WC, Yamauchi LM, Foglio MA, Eberlin MN, Mello JC, Costa FT. In vitro and in vivo assessment of the anti-malarial activity of Caesalpinia pluviosa. Malaria J, 2011; 10: 112

Khatun BR, Rahman MO. Taxonomic revision of the genus Caesalpinia L. (Caesalpiniaceae) for Bangladesh. Bangladesh J Plant Taxon, 2006; 13: 93-109.

Kinoshita T, Haga Y, Narimatsu S, Shimada M, Goda Y. The isolation and structure elucidation of new cassane diterpene-acids from Caesalpinia crista L. (Fabaceae), and review on the nomenclature of some Caesalpinia species. Chem Pharm Bull, 2005; 53: 717-720.

Kshirsagar SN. Nootropic activity of dried seed kernels of Caesalpinia crista Linn. against scopolamine-induced amnesia in mice. Int J PharmTech Res, 2011; 3: 104-109.

Kumar A, Garg V, Chaudhary A, Jain PK, Tomar PK. Isolation, characterisation and antibacterial activity of new compounds from methanolic extract of seeds of Caesalpinia crista L. (Caesalpinaceae). Nat Prod Res, 2014; 28: 230-238.

Kumar RS, Narasingappa RB, Joshi CG, Girish TK, Danagoudar A. Caesalpinia crista Linn. Induces protection against DNA and membrane damage. Pharmacogn Mag, 2017; 13(Suppl 2): S250.

Kumar SR, Kumar SA. Cardioprotective effect of Caesalpinia crista Linn. on isoproterenol induced myocardial necrosis in rats. Int J Res Pharm Sci, 2013; 3: 119-130.

Kuria KA, De Coster S, Muriuki G, Masengo W, Kibwage I, Hoogmartens J, Laekeman GM. Antimalarial activity of Ajuga remota Benth (Labiatae) and Caesalpinia volkensii Harms (Caesalpiniaceae): In vitro confirmation of ethnopharmacological use. J Ethnopharmacol, 2001; 74: $141-148$.

Li SJ, Zhang DX, Li L, Chen ZY. Pollination ecology of Caesalpinia crista (Leguminosae: Caesalpinioideae). Acta Bot Sin, 2004; 46: 271-278.

Linn TZ, Awale S, Tezuka Y, Banskota AH, Kalauni SK, Attamimi F, Ueda J, Setia Asih PB, Styfruddin D, Tanaka K, Kadota S. Cassane- and norcassane-type diterpenes from Caesalpinia crista of Indonesia and their antimalarial activity against the growth of Plasmodium falciparum. J Nat Prod, 2005; 68: 706-710.

Liu QB, Huang L, Zhang L, Liu Q, Xu QQ, Qin XJ, Fang XY, Zeng Y. Two new cassane-type diterpenes from the seeds of Caesalpinia crista. J Asian Nat Prod Res, 2015; 17: 1073-1078.

Ma G, Sun Z, Sun Z, Yuan J, Wei H, Yang J, Wu H, Xu X. Antimalarial diterpene alkaloids from the seeds of Caesalpinia minax. Fitoterapia, 2014; 95: 234-239.

Ma G, Wu H, Chen D, Zhu N, Zhu Y, Sun Z, Li P, Yang J, Yuan J, $\mathrm{Xu} \mathrm{X}$. Antimalarial and antiproliferative cassane diterpenes of Caesalpinia sappan. J Nat Prod, 2015; 78: 2364-2371.

Mandal S, Hazra B, Sarkar R, Biswas S, Mandal N. Assessment of the antioxidant and reactive oxygen species scavenging activity of methanolic extract of Caesalpinia crista leaf. Evid-based Complement Altern Med. 2011; ID 173768: 11 pp.

Maurya R, Ravi M, Singh S, Yadav PP. A review on cassane and norcassane diterpenes and their pharmacological studies. Fitoterapia, 2012; 83: 272-280.

Moon K, Khadabadi SS, Deokate UA, Deore SL. Caesalpinia bonducella F. - An overview. Rep Opin, 2010; 2: 83-90.
Murphy MP, LeVine III H. Alzheimer's disease and the $\beta$-amyloid peptide. J Alzheimers Dis, 2010; 19: 311-323.

Nakazawa Y, Nagatomo M, Oikawa T, Oikawa M, Ishikawa Y. Studies directed toward synthesis of taepeenin D: Construction of the C4 stereogenic center and the CD benzofuran rings. Tetrahedron Lett, 2016; 27: $2628-2630$.

Nathala E, Dhingra S. Biological effects of Caesalpinia crista seed extracts on Helicoverpa armigera (Lepidoptera: Noctuidae) and its predator, Coccinella septumpunctata (Coleoptera: Coccinellidae). J AsiaPac Entomol, 2006; 9(2): 159-164.

Neli S, Kalita J. The potential pollinators of Caesalpinia crista (Leguminosae: Caesalpinioidae). Bioscan, 2013; 8: 37-41.

Ogunlana OO, Ogunlana OE. Antiplasmodial flavonoid from young twigs and leaves of Caesalpinia bonduc (Linn) Roxb. J Chem Pharm Res, 2015; 7: 931-937.

Palasap A, Limpaiboon T, Boonsiri P, Thapphasaraphong S, Daduang S, Suwannalert P, Daduang J. Cytotoxic effects of phytophenolics from Caesalpinia mimosoides Lamk. On cervical carcinoma cell lines through an apoptotic pathway. Asian Pac J Cancer Prev, 2013; 15: 449454.

Patil KS. Wound healing activity of the seed kernels of Caesalpinia crista Linn. J Nat Remed, 2005; 5: 26-30.

Patil U, Sharma MC. Antiviral activity of lathakaranja (Caesalpinia crista L.) crude extracts on selected animal viruses. Global J Res Med Plants Indigen Med, 2012; 1: 440-447.

Pranithanchai W, Karalai C, Ponglimanont C, Subhadhirasakul $\mathrm{S}$, Chantrapromma K. Cassane diterpenoids from the stem of Caesalpinia pulcherrima. Phytochemistry, 2009; 70: 300-304.

Ramesh BN, Girish TK, Raghavendra RH, Naidu KA, Prasada Rao UJS, Rao KS. Comparative study on antioxidant and anti-inflammatory activities of Caesalpinia crista and Centella asiatica leaf extracts. J Pharm BioAllied Sci, 2014; 6: 86-91.

Ramesh BN, Indi SS, Rao KSJ. Anti-amyloidogenic property of leaf aqueous extract of Caesalpinia crista. Neurosci Lett, 2010; 475: 110114.

Rifai Y, Arai MA, Koyano T, Kowithayakorn T, Ishibashi M. Terpenoids and a flavonoid glycoside from Acacia pennata leaves as hedgehog/GLI-mediated transcriptional inhibitors. J Nat Prod, 2010; 73 995-997.

Samuel AJ, Kalusalingam A, Chellappan DK, Gopinath R, Radhamani S, Husain HA, Muruganandham V, Promwichit P. Ethnomedical survey of plants used by the Orang Asli in Kampung Bawong, Perak, West Malaysia. J Ethnobiol Ethnomed, 2010; 6(1): 5 pp.

Sarkar R, Hazra B, Mandal N. Hepatoprotective potential of Caesalpinia crista against iron-overload-induced liver toxicity in mice. Evid-based Complement Altern Med, 2012; Article ID 896341: 9 pp.

Satnami DK, Yadava RN. Potential phytochemical from Caesalpinia crista Linn. Res J Phytochem, 2011; 5: 22-31.

Selkoe DJ. Alzheimer's disease results from the cerebral accumulation and cytotoxicity of amyloid beta protein, J Alzheimers Dis, 2001; 3: 75-80

Singhal A. Chromatographic analysis and anthelmintic activity of the seed oil of Caesalpinia crista. Asian J Chem, 2007; 19: 3577-3580.

Suryawanshi HP, Patel MR. Traditional uses, medicinal and phytopharmacological properties of Caesalpinia crista Linn. - An overview. Int J Res Pharm Chem, 2011; 1: 1179-1183.

The Plant List, Caesalpinia, 2013. Database available online at http://www.theplantlist.org.

Tian QJ, Ou YH, He XB, Bing-Liu, Jiang YD. One new antitumour cassane-type diterpene from Caesalpinia crista. Nat Prod Res, 2013; $27:$ 537-540.

Wu M, Wang YF, Zhang ML, Huo CH, Dong M, Shi QW, Kiyota H. Chemical constituents of plants from the genus Caesalpinia. Chem Biodiver, 2011; 8: 1370-1399.

Yang ZY, Yin YH, Hu LH. Five new cassane-type diterpenes from Caesalpinia crista. Helv Chim Acta, 2009; 92: 121-126. 
Zaman K, Chetia D, Ali M. Isolation of two new cheilanthanetype tricarbocyclic sesterterpenoids from leaves of Caesalpinia crista Linn: A traditionally used antimalarial plant of Assam, India. Asian J Chem, 2017; 29: 485-488

Zanin JL, De Carvalho BA, Martineli PS, Dos Santos MH, Lago JH, Sartorelli P, Viegas C, Soares MG. The genus Caesalpinia L. (Caesalpiniaceae): Phytochemical and pharmacological characteristics. Molecules, 2012; 17: 7887-7902.
How to cite this article:

Chan EWC, Tangah J, Baba S, Chan HT, Kainuma M, Inoue T. Caesalpinia crista: A coastal woody climber with promising therapeutic values. J App Pharm Sci, 2018; 8(03): 133-140. 